Papers and Proceedings of the Royal Society of Tasmania, Volume 108

(ms. received 30.11 .1973 )

\title{
STATUS AND SUBDIVISION OF THE PARMEENER SUPER-GROUP
}

\author{
by \\ S.M. Forsyth ${ }^{1}$, N. Farmer ${ }^{1}$, A.B. Gulline ${ }^{1}$, M.R. Banks ${ }^{2}$, \\ E. Williams ${ }^{1}$, M.J. Clarke ${ }^{1}$. \\ 1. Geological Survey of Tasmania, \\ 2. Geology Department, University of Tasmania \\ (with one text figure)
}

\begin{abstract}
$\underline{\text { ABSTRACT }}$
Late Palaeozoic and Early Mesozoic rocks of the Parmeener Super-Group are subdivided on a strict lithostratigraphical basis, and not in the time terms 'Permian' and 'Triassic'.
\end{abstract}

\section{DISCUSSION}

The name Parmeener Super-Group (Banks 1973) has recently been introduced to define a widespread Tasmanian sequence of Late Palaeozoic and Early Mesozoic rocks. These strata are almost always sub-horizontal, and they rest with pronounced landscape unconformity on a folded basement which includes rocks as young as Late Devonian or Early Carboniferous. The Parmeener Super-Group ranges in age from Late Carboniferous to Late Triassic, and this litho-stratigraphical unit has at many localities often been incorrectly described in the international time-rock unit terms. Whereas no further formal subdivision of the Parmeener Super-Group was proposed in the original definition, it was indicated that everywhere in Tasmania two broad lithological and environmental associations can be recognised. These are (1) a lower division which includes all glacial and glaciomarine beds; and (2) an upper and essentially freshwater division. Both divisions include subordinate coal measures.

The Permian/Triassic boundary, which has been used as a major division of the Parmeener Super-Group in the past, does not coincide with the boundary between the two broad lithological units, but occurs within the lower part of the essentially freshwater division. The Permian/Triassic boundary has proved unsatisfactory because of lack of fossils and it cannot be determined with sufficient accuracy for mapping purposes. The litho-stratigraphical boundary between the two major rock units, however, can be determined accurately during routine mapping, and it is proposed that this division be referred to in future.

The boundary between the Lower [division of the] Parmeener Super-Group and the Upper [division of the] Parmeener Super-Group is here defined as that between the 'Upper Marine Sequence' and the 'Upper Freshwater Sequence' of Clarke and Banks (in press) and Clarke, Farmer and Gulline (in press). It occurs at the base of the Cygnet Coal Measures (Late Permian) in southern Tasmania, and at the base of correlative horizons such as the Jackey Formation (Late Permian) at Poatina. In detail the Lower division includes such characteristic units as the Wynyard Tillite Formation, the Quamby Formation, the Golden Valley Group, the Masseys Creek Group, the Woody Island Siltstone Formation, the Darlington Limestone and the Bundella Formation (='Lower Marine Sequence'); the Liffey Group, the Mersey Coal Measures, the Faulkner Group and the Preolenna Coal Measures (='Lower Freshwater Sequence'); and the Cascades Group, the Malbina Formation, the Risdon Sandstone, the Ferntree Mudstone, the Poatina Group and the Bogan Gap Group (='Upper Marine Sequence'). 


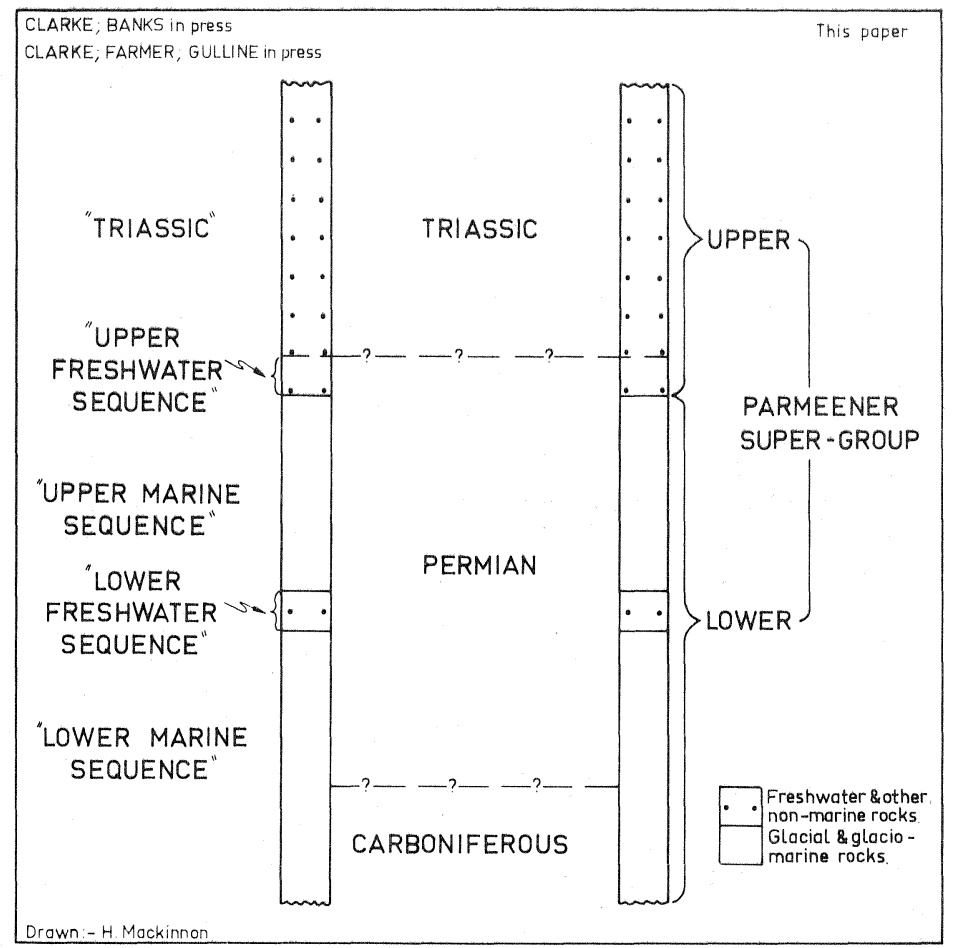

The Sequences indicated in the diagram include the following characteristic units:

'Triassic' - Ross Sandstone Formation, Cluan Formation, Tiers Formation, Brady Formation, Springs Sandstone Formation and Knocklofty Formation.

'Upper Freshwater Sequence' - Cygnet Coal Measures, Jackey Formation, Clog Tom Sandstone Formation.

'Upper Marine Sequence' - Cascades Group, Malbina Formation, Ferntree Group, Poatina Group and Bogan Gap Group.

'Lower Freshwater Sequence' - Liffey Group, Faulkner Group, Mersey Coal Measures and Preolenna Coal Measures.

'Lower Marine Sequence' - Wynyard Tillite Formation, Quamby Formation, Golden Valley Group, Masseys Creek Group, Woody Island Siltstone Formation, Darlington Limestone Formation, Spreyton Beds, Kansas Creek Formation and Bundella Formation. 
S.M. Forsyth, N. Farmer, A.B. Gulline, M.R. Banks, E. Williams, M.J. Clarke

The Upper division includes the Cygnet Coal Measures, the Jackey Formation and the Clog Tom Sandstone Formation (='Upper Freshwater Sequence'); and the Ross Sandstone Formation, the Cluan Formation, the Tiers Formation, the Brady Formation, the Springs Sandstone Formation, the Knocklofty Formation and the Triassic coal measures (='Triassic').

In other words, the subdivision of Tasmanian Late Palaeozoic and Early Mesozoic rocks is based on local lithostratigraphical considerations. This procedure is considered to be an improvement on previous practice since neither the Permo-Carboniferous boundary nor the Permo-Triassic boundary can be located with any accuracy in Tasmania. All printed geological maps issued by the Geological Survey of Tasmania after July 1973, will incorporate the proposed lithostratigraphic subdivisions.

\section{REFERENCES}

Banks, M.R., 1973: General Geology in The Lake Country of Tasmania. Royal Society of Tasmania, 25-34.

Clarke, M.J, and Banks, M.R. (in press): The Stratigraphy of the lower (Permo-Carboniferous) parts of the Parmeener Super-Group. Proc. 3rd Int. Gondwana Symp., Canberra 1973. (A.N.U. Press).

Clarke, M.J., Farmer, N॰, Gulline, A.B. (in press): Parmeener Super-Group, Tasmania. Economic Geology of Australia and Papua-New Guinea. (Petroleum Volume). Australas. Inst. Min. Metalz. 